UDC 339.9:338.1

JEL: E03 F63, O38, P50

\section{Yuliya Orlovska}

Doctor of Economic Sciences,

Professor,

Pridniprovska State Academy of Civil

Engineering And Architecture,

Dnipro, Ukraine

E-mail: juliaorlov@ukr.net

orcid.org/0000-0003-0966-931X

\section{Svetlana Morozova}

Pridniprovska State Academy of Civil

Engineering And Architecture,

Dnipro, Ukraine

E-mail: Artsvetlanka@gmail.com

orcid.org/0000-0002-0118-3502

Received: February, 2019

Accepted: April, 2019

DOI:10.31520/2616-7107/2019.3.2-5

(C) Economics. Ecology. Socium, 2019

CC BY-NC 4.0 license

\section{INNOVATION MODERNIZATION OF UKRAINE'S ECONOMY TAKING INTO CONSIDERATION THE EU'S EXPIRIENCE}

Introduction. At the beginning of the 21 st century, most Western countries, faced with the need to find ways to grow, began to realize that the post-industrial economy can no longer act as a reliable foundation for economic development. It should be noted that Ukraine's place in world innovation processes does not yet match the potential of the country. Lack of funding for research and development, especially fundamental science, will lead to further outflow of highly skilled scientific personnel, loss of prospects for the growth of national competitiveness on world markets of innovative products and irreversible lagging behind developed countries.

Aim and tasks. The aim of the research is to develop the general provisions of the systematic study of the patterns of innovation development of European countries in the context of global transformations and to justify on this basis the directions of innovation modernization of the Ukrainian economy.

Results. Three fundamentally different variants of development of economic systems are determined depending on the choice of technological basis of economic growth. The prerequisites for formation of the strategy of innovation modernization of the Ukrainian economy are substantiated, namely: resource support; technological update; institutional support; development of infrastructure and regulatory support; strengthening of business reputation and access to the foreign market; increase of competitiveness of Ukrainian enterprises in the world market of goods and services. The model of innovative modernization of economic development with the account of the experience of the EU member states as a form of private-public partnership with the use of science-intensive technologies (on technological platforms) is offered.

Conclusions. According to the results, it is determined that the effective system of innovative modernization of the Ukrainian economy has not yet been formed. The following areas are suggested for the urgent directions of solving this problem: fundamental development and theoretical substantiation of the types of public-private partnership; ensuring transparency of the system of stimulation of domestic innovation projects; formation of a stable information field, which includes a set of data on a number of issues that arise (between private, state and mixed structures), as well as in the process of generating and using financial resources for the purpose of innovative development of the domestic economy.

Keywords: innovation development, economic system, European countries, modernization of economy. 
УДК 339.9:338.1

JEL: E03 F63, O38, P50

\section{Юлія Орловська}

Доктор економічних наук, професор,

ДВНЗ «Придніпровська державна академія будівництва та архітектури»

м. Дніпро, Україна

E-mail: juliaorlov@ukr.net

orcid.org/0000-0003-0966-931X

\section{Світлана Морозова}

ДВНЗ «Придніпровська державна академія будівництва та архітектури» м. Дніпро, Україна E-mail: Artsvetlanka@gmail.com orcid.org/0000-0002-0118-3502

Отримано: Лютий, 2019

Прийнято: Квітень, 2019

DOI:10.31520/2616-7107/2019.3.2-5

(C) Економіка. Екологія. Соціум, 2019 CC BY-NC 4.0 ліцензія

\section{ІННОВАЦІЙНА МОДЕРНІЗАЦІЯ ЕКОНОМІКИ УКРАЇНИ 3 УРАХУВАННЯМ ДОСВІДУ ЄС}

Вступ. На початку XXI століття більшість західних країн, зіткнувшись 3 необхідністю пошуку шляхів економічного зростання, стали усвідомлювати, що постіндустріальна економіка більше не може виступати в якості надійного підгрунтя економічного розвитку. Необхідним базисом такого розвитку $\epsilon$ матеріальне виробництво, традиційна зайнятість на підприємствах, які виробляють матеріальний продукт та в якому формується попит на інновації, що забезпечує динамічний розвиток інноваційної економіки. Слід зазначити, що місце України в світових інноваційних процесах поки не відповідає наявному в країні потенціалу. Недостатне фінансування наукових досліджень i розробок, особливо фундаментальної науки, призведе до подальшого відтоку висококваліфікованих наукових кадрів, втрати перспектив зростання національної конкурентоспроможності на світових ринках інноваційної продукції та незворотного відставання від розвинених країн.

Мета і завдання. Метою дослідження є розроблення загальних положень системного дослідження закономірностей інноваційного розвитку європейських країн в умовах глобальних трансформацій та обгрунтування на цій основі напрямів інноваційної модернізації української економіки.

Результати. Визначено три принципово різних варіанти розвитку економічних систем в залежності від вибору технологічної основи економічного зростання. Обгрунтовано передумови формування стратегії інноваційної модернізації економіки України. Запропоновано модель інноваційної модернізації економічного розвитку з врахуванням досвіду країн-членів ЄC як форми приватно-державного партнерства із застосуванням наукоємних технологій (на технологічних платформах).

Висновки. За отриманими результатами визначено, що дієва система інноваційної модернізації економіки України ще не сформована. Актуальними напрямами вирішення цієї проблеми запропоновано такі: фундаментальна розробка $\mathrm{i}$ теоретичне обгрунтування видів державно-приватного партнерства; забезпечення прозорості системи стимулювання вітчизняних інноваційних проектів; формування стійкого інформаційного поля, що включає в себе сукупності даних по тих чи інших питань, а також в процесі генерування та використання фінансових ресурсів 3 метою інноваційного розвитку вітчизняної економіки.

Ключові слова: інноваційний розвиток, економічна система, європейські країни, модернізація економіки. 
Introduction. Formation of a productive economic system at any level requires the definition of the trajectory of innovation development, and on its basis the allocation of so-called "points" of this development, which in the 21 st century turn into a global multiresources system and, ultimately, orient the subjects of the innovation process on productive search of each other. At the present stage of the innovation development of the world economy, a number of areas which are worthy of attention due to the diversity of the possibilities offered by them for the choice of the trajectory of innovative development of economic systems and the relatively high adaptability of the considered trajectories to economic realities is well developed.

The vast majority of methods used in practice to predict the development of economic systems is limited to forecasting the quantitative values of certain parameters of economic development. The limitation of this principle stems from the fact that forecasts are based on the presumption of the preservation of "existing trends", but in reality, there is a fact that it is impossible to predict the moment of change in trends that are essential for understanding the development of the National Innovation System (NIS) that is being investigated. To overcome such a disadvantage is possible with the application of a method that predicts qualitative vectors, the general nature of the development of events, and quantitative parameters are predicted only within each individual method, based on the general logic. For example, a methodological approach in the form of scenario forecasting can be used in situations when it is necessary to make decisions that affect the innovative development of the subject. In particular, this concerns the tasks of state management of the innovative development of the national economy.

At the beginning of the 21 st century, most Western countries, faced with the need to find ways to grow, began to realize that the postindustrial economy can no longer act as a reliable foundation for economic development. Necessary basis for such development is material production, traditional employment at enterprises that produce a material product and in which the demand for innovation is created, which ensures the dynamic development of an innovative economy.
As a consequence, the European Commission published in January 2014 a special communique entitled "For a European Industrial Renaissance," it was noted that the future success of the EU depends on the existence of a strong, diversified and sustainable growth model, where industry plays a key role [1]. That is, the renewal and improvement of the industrial base will make the real sector a leader in the economic recovery of Europe.

It should be noted that Ukraine's place in world innovation processes does not yet match the potential of the country. The current state of innovative development of the domestic economy is characterized by a number of problems that require a solution to improve the economic situation in the country (see $[2 ; 3]$ ). in more detail). Lack of funding for research and development, especially fundamental science, will lead to further outflow of highly skilled scientific personnel, loss of prospects for the growth of national competitiveness on world markets of innovative products and irreversible lagging behind developed countries. Taking into account the aforementioned, the importance of studying possible variants of innovation modernization of the Ukrainian economy takes into account the experience of the European Union countries.

Analysis recent research and publications. Theoretical and methodological and methodical and applied aspects of innovative development of countries and mechanisms for its improvement attracted the attention of both foreign and domestic scientists. Thus, the problems of the interconnectivity of competitiveness, innovation and productivity were studied by Atkinson R. [4], Nelson R. [5], Kaiser R. and Prange H. [6]. The Influence of Innovation Change on Economic Development Dosi G. [7], Nadiri M. [8]. The historical and analytical foundations of the innovative development model have attracted the attention of Godin B. [9] and others. The leading domestic researchers in solving the problems of developing an innovative economy are Heyets V. [10], Duginets G. [11], Kvasha O. [12], Marchuk L. [13], Koval V., Weis L. [14-15] and other. The resulting processing forms the theoretical and methodological basis for this study. 
In modern conditions, scientific literature does not provide a sufficiently complete picture of the directions of possible improvement and improvement of the innovative development of the national economy taking into account the current stage of European integration of Ukraine. For example, to date, the problem of substantiation of the directions of innovation modernization of the economic system has not been completely solved. Therefore, the high evaluation of the above named scientists and the results of their research, it should be noted that these processes require a more thorough analysis.

Aim and tasks. The purpose of the research is to develop the general provisions of the systematic study of the patterns of innovation development of European countries in the context of global transformations and to justify on this basis the directions of innovation modernization of the Ukrainian economy.

Results. (Presentation of the main material and the substantiation of the results of the study). The current state of the NIS of Ukraine for a variety of parameters can be characterized as a state of unsustainable development. The main features of the modern period in the development of the domestic economy are the onset of depression - the phase that lays the economic and structural conditions for the economic development of systems and large-scale technological changes that begin on the ascending wave of the industrial cycle. At the same time, in our country, technological potential, if not continues to collapse, does not revive, which in turn negatively affects the starting conditions of the expected recovery.

It should be noted that there are three fundamentally different variants of the development of economic systems, depending on the choice of technological basis of economic growth. Consider three scenarios for the formation of innovative economic systems.

1. Modernization of the economy. This scenario is based on the fact that the state will implement a strategy of active stimulation of innovation processes and will direct efforts on the wide production of new equipment and the introduction of elements of the sixth technological structure, while trying to remove the technologically backward elements from the investment process.
The development of the economy on such a trajectory is possible only on the basis of scientific development and implementation of a comprehensive federal program of financing innovative activity. Appropriate steps are accompanied by the centralization of financial resources, redistribution of budget functions, strict control over the implementation of research activities and the introduction of domestic developments in mass production.

The development of the economy under this scenario in the short term will be due to the main source of accumulation - natural rent, as well as domestic and foreign loans, and the basis for their repayment should be the intellectual and innovative rent, created as a result of the application of new technologies and environmentally friendly industries in the country. The use of natural rent allows us to find the necessary time for the implementation of innovative projects and programs, and already at the fifth to sixth year of the modernization of the economy the role of innovation rent, increase of domestic sources of accumulation will increase rapidly. The first scenario considered is best for implementation within the Ukrainian economy under the current conditions of its development.

2. Expecting the best times. This scenario is based on the assumption that in the future the modernization strategy for the domestic economy is not conducive, so the state will take the course of introducing into the production of elements of the widespread technological process in the most developed countries. It will also try to push out the production process more backward and, if possible, create conditions for a further breakthrough in the economy (after 10 -12 years). This catch-up scenario is the least effective and most expensive one. This approach, based on a pessimistic assessment of the technological potential of the country, implies a high level of state influence on investment decisions, relying on the development of export-oriented commodity sectors as the main source of replenishment of the state budget (a widespread strategy for the development of the Ukrainian economy in recent years). This approach will lead to a reduction in a large part of expensive research projects and programs, to partially disperse existing scientific and technical potential. 
This approach in the short term also implies a sharp decline in real consumption, but after about four to five years, relative stabilization is taking place, but the living standards of the population will be somewhat worse than in the first scenario. With such developments, the main danger is that the state will outlook strategic goals and not notice the possibility of modernizing the economy, investments in innovative production will be inflationary in nature, which will lead to structural distortions in the economy. At this time, it is advisable to prepare and implement a technological breakthrough, concentrating technological and investment potential on the key vectors of scientific and technological progress.

3. The third approach based on deregulation follows from the fact that the technological basis of production processes does not require the government to make decisions on fundamentally important issues of modernizing the economy. This scenario implies weakening the role of the state in economic transformations and conducting liberal market reforms. As a result of adopting such a scenario, a significant decrease in the standard of living of the population will occur, which may cause a shock to public life. In general, this scenario is the degradation of the economy, due to the transformation of our country into a dependent appendage of more developed countries. Three scenarios of innovation development of the economy are connected with realization of three possible variants:

- modernization of the economy, which promotes a technological breakthrough through the implementation of available scientific and technical potential;

- waiting strategy with structurally balanced growth and rate on resource potential;

- a strategy of deregulation, which implies non-interference of the state in the market mechanism of the functioning of the economic system with the absence of its own industrial policy and the use of forced short-term measures dictated by foreign capital.

Of course, the implementation of a consistent policy, even an exhilarating one, based on underestimation of the scientific and technological potential, on the lack of confidence in innovative ideas and prospects for the development of the domestic economy, nevertheless leads to far better consequences than the lack of scientifically based programs and measures for the development of the innovation system. At the same time, the focus on radical changes and rapid implementation in the production processes of IT-technologies is a real variant of the development of economic systems from among existing ones.

Summarizing the results of the analysis of various scientific positions on the problem considered in this paper, it can be determined that the process of interaction of economic actors in national innovation systems is due to certain factors of economic development. First, ensuring the integrity of the innovation process and raising the systemic quality of interaction between actors in it, and secondly, modernizing the elements of infrastructure, human and financial capital that make up this structure. Thus, innovative modernization of the Ukrainian economy defines the goals, tasks, directions and forms of activity of state authorities in the field of innovations. Moreover, the main functions of state regulation in the innovation sphere are:

- establishment of national priorities of the strategy of innovation development with the appropriate coordination of activities of the entities that implement it;

- stimulation of innovation activity, competition in the innovation sphere, including state sanctions for the production of obsolete products;

- consolidation of financial resources for research and development, organization of financing of the strategy of innovation development;

- regulation of international aspects of the strategy of innovation development of the national economy, with mandatory legal regulation of innovation activity, protection of copyright, protection of intellectual property;

- staffing of implementation of the strategy of innovation development;

- formation of a specific institutional environment of the strategy of innovation development.

In today's economic paradigm, there is an existing system of measures for the creation and development of an innovative economic model. 
Therefore, in general, the state supports and stimulates innovation through the formation and development of an innovative component of the economy at various levels. Moreover, all methods used in general form can be divided into direct and indirect (Figure. 1).

Direct methods are implemented in the administrative-command and program-target forms. The administrative-command form of development of the innovative component of the economy is manifested in the form of direct financing of innovation projects from budgets of different levels in accordance with the law. In turn, the program-targeted method involves specific funding of programs through statesponsored innovation.
The main functions of the authorities in the interaction with the formation and development of the innovative component of the economy are the following: coordination of innovation activities; accumulation of funds for science; stimulating innovation; insurance of innovative risks; staffing of innovative production; formation of innovation infrastructure; institutional provision of innovative production in the public sector; provision of social and environmental orientation of innovations; the introduction of state sanctions for the production of obsolete noncompetitive products; creation of the legal basis of innovation production; regulation of international aspects of innovation production.

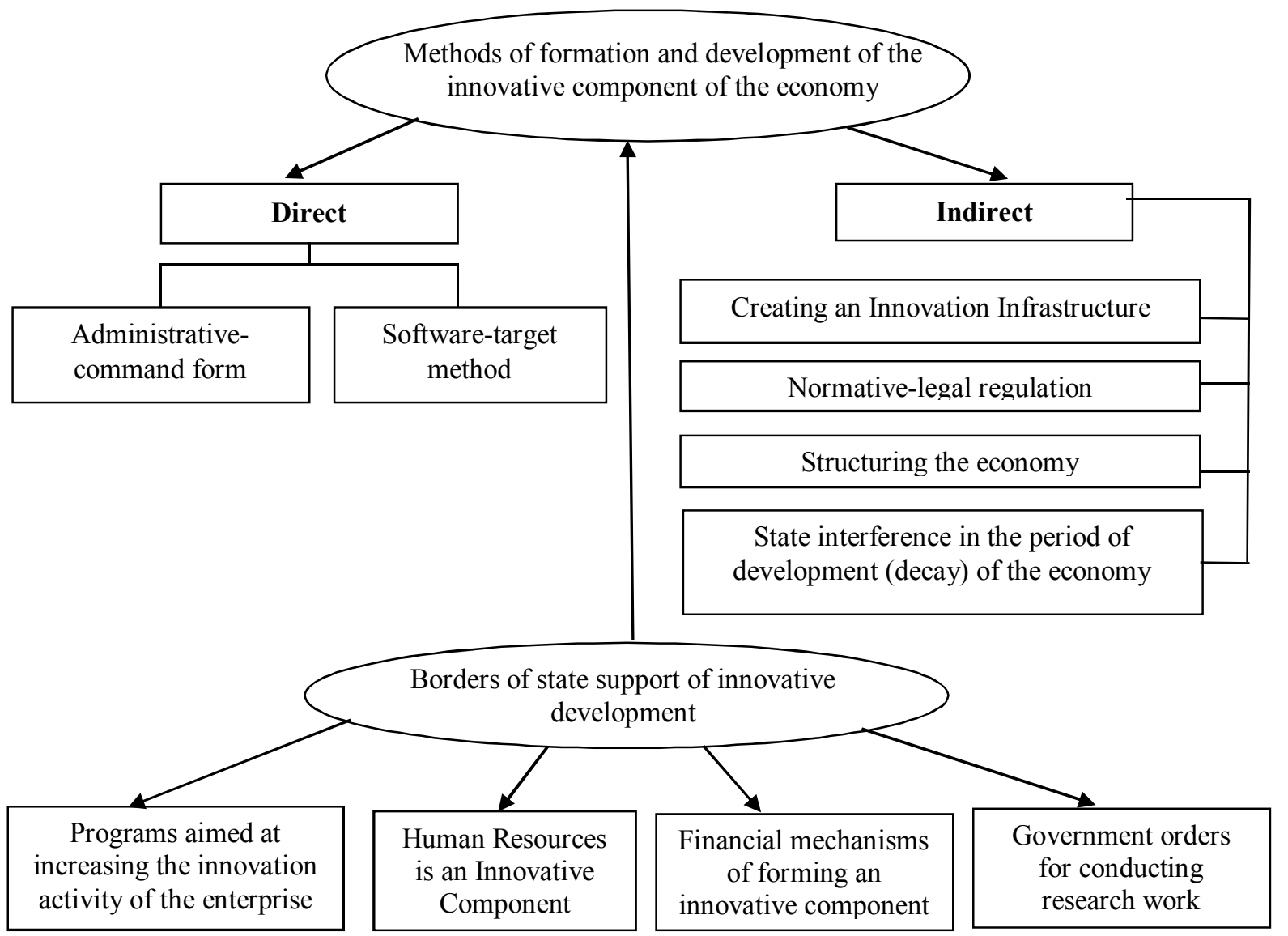

Fig. 1. Methods of formation and development of the innovative component of the economy Source: compiled by the authors.

In the context of this study, it should be noted that the systematic approach to the formation of an innovation development strategy is based on the joint use of direct and indirect methods. In this case, the geographical proximity of participants in the innovation process is important in their interaction. As M. Polanyi noted in 1958 [16], knowledge has an implicit component that cannot be transmitted over long distances, but extends through personal communication and the exchange of experience of knowledge carriers. The closer the parties to the innovation process are to each other, the cheaper, more complete, and therefore, this interaction will be more effective [17]. 
This approach allows to effectively develop innovative processes on the basis of innovative modernization of mechanisms of using existing resources and economic opportunities within the framework of forming and increasing the adaptability of the innovation process. It also allows to balance the innovative potential of economic development in order to ensure the sustainability of the innovative component. Thus, it is possible to determine the preconditions for forming a strategy for innovation modernization of the Ukrainian economy (fig. 2). At the heart of its construction are the following principles: resource support; technological update; institutional support; development of infrastructure and regulatory support; strengthening of business reputation and access to the foreign market; increase of competitiveness of Ukrainian enterprises in the world market of goods and services.

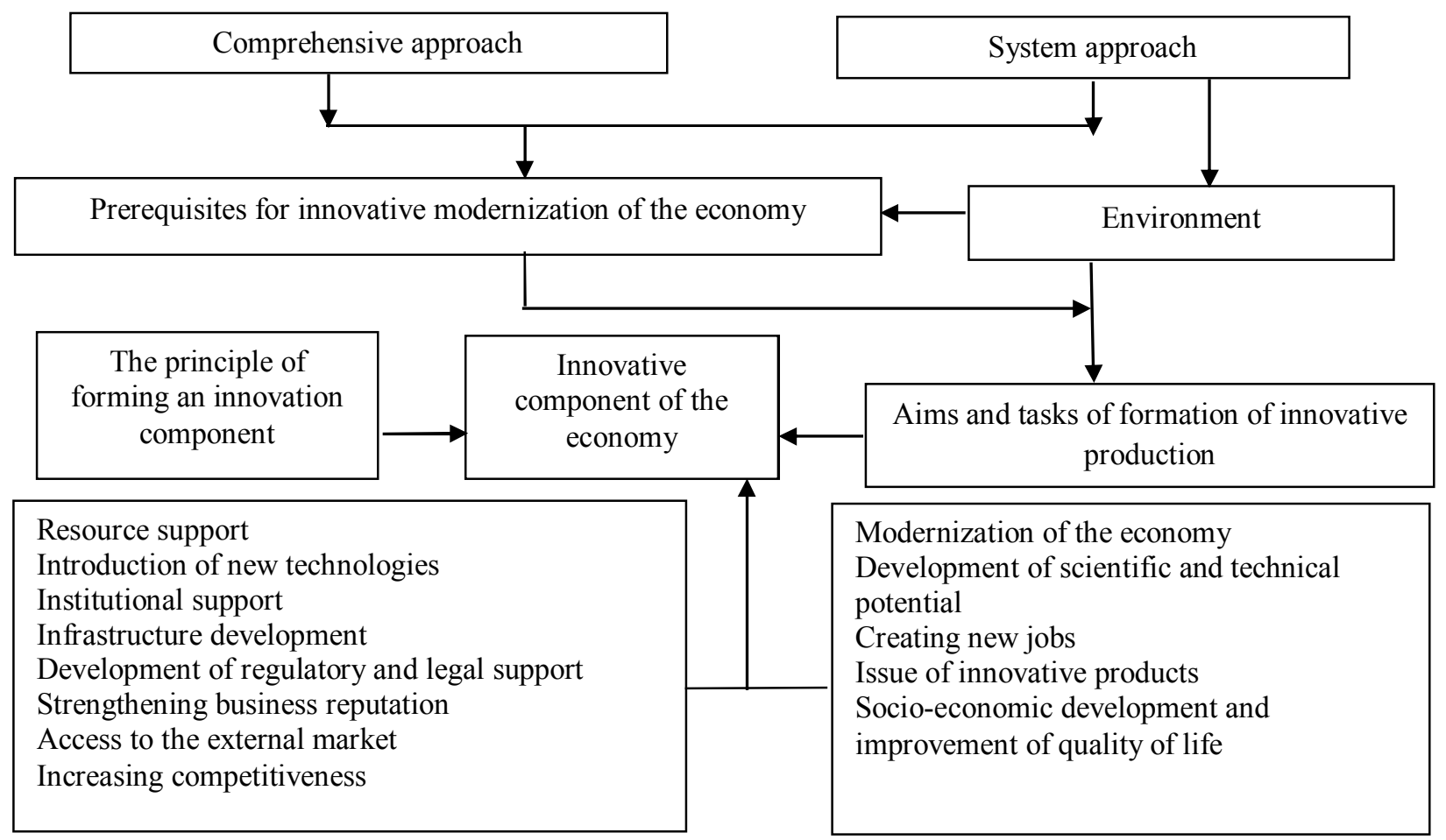

Fig. 2. Prerequisites for the strategy of innovation modernization of the Ukrainian economy Source: compiled by the authors.

The principle of resource provision within the framework of strategic innovation modernization of the Ukrainian economy is characterized by such aspects as the economic status of economic entities engaged in innovative production, the availability of a complex of resources (raw materials, intellectual property, energy) necessary for their functioning, and the degree of efficiency of the use of these resources.

In addition, as the experience of EU member states shows, effective innovative development depends on the integrated implementation of the following directions of innovation policy:

1. Development of institutes engaged in research and development. Modern trends in the development of educational systems and research require the state to support the processes of modernization of universities, research institutes, research units of companies, laboratories. Key measures may include not only direct subsidization of research, grants, but also support in acquiring the necessary equipment, materials, etc.

2. Development of the public-private partnership institute. An illustrative example in this case is the innovative transformations of the 1990s. in Finland. As a result of the systemic approach to innovation policy using public-private partnership, this country ranked third in the world in terms of investment in the information and communications technology sector after Sweden and Israel, while in the 1970 's the 20th century. its economy was mainly resourceful. 
3. Stimulating small and medium innovation entrepreneurship. As previously mentioned, in EU member states up to $70 \%$ of all innovations create and develop small and medium-sized innovation enterprises, scientific and technical and engineering centers with large industrial corporations. They determine the scientific, technical and innovation policies of corporations and ensure the high competitiveness of production. However, it should be noted that shifting the priority of state support towards small innovative entrepreneurship is possible only with the stable and efficient work of large companies. Thus, the actual direction is to stimulate the innovation initiative of national companies, with key measures of this direction being the improvement of tax and budget legislation, as well as the expansion of public procurement and budget subsidies.

4. Development of the system of education and vocational training, increasing the mobility of the workforce. It is at the expense of the accumulation and use of "human capital" that economic entities obtain a rent, similar in content to income from investments in securities or from loans. As a result, the struggle for ownership of the rent is intensified on the national and international markets. Consequently, there is a need for measures that minimize the damage to the national innovation system from this type of competition, such as: creating a system of advanced training and retraining of professional staff in the field of innovation; creation of a platform for the exchange of knowledge and experience of young professionals; improving the quality and prestige of higher education.

It should be noted that each EU member state has its own peculiarities of the development of vocational education. Thus, in Germany, the policy of vocational education is characterized by a high degree of social orientation. In higher education institutions, programs are being implemented that aim at creating graduates with the knowledge and skills necessary to organize their own innovative start-ups and enterprises. In Belgium and the Netherlands, special attention is paid to the compliance of training of graduates with high professional standards, which further ensures their participation in international scientific and technical programs. In the UK, the focus is on enhancing the prestige of engineering specialties, which is in line with the general policy of attracting leading foreign electronics and engineering companies to the region.

5. Saving and developing strategically important technologies. Measures of state innovation policy should ensure breakthrough results in the areas of knowledge that create competitive advantages in strategically important areas for the economy that provide a long-term presence in the system of making global decisions. Key measures can be the creation of innovative infrastructure and a favorable innovation climate in the country, facilitate interaction between business and creators of knowledge and technology in all sectors.

Therefore, based on the analysis, comparison and study of the experience of innovation development in the EU, conclusions can be drawn about the consequences of certain measures in the presence of a specific configuration of factors for the country where these measures can be applied. In order that certain strategies for the development of individual elements of the economic system of European countries become a set of measures and rules aimed at implementing the overall strategy of innovation development of Ukraine, to rationally combine them into the main stages of modeling the strategy (fig. 3).

It should be noted that within the framework of monitoring the quality of implementation of the complex of measures taken, it is necessary to monitor the indicators of the functioning of the elements of innovation infrastructure in relation to the target values of indicators of the level of innovation development of the regional industrial complex. With the deviation of the indicators of the existing innovative infrastructure from the required values of indicators carried out, or clarification of the targets of the strategy of innovation development, or change and adjustment of measures. 


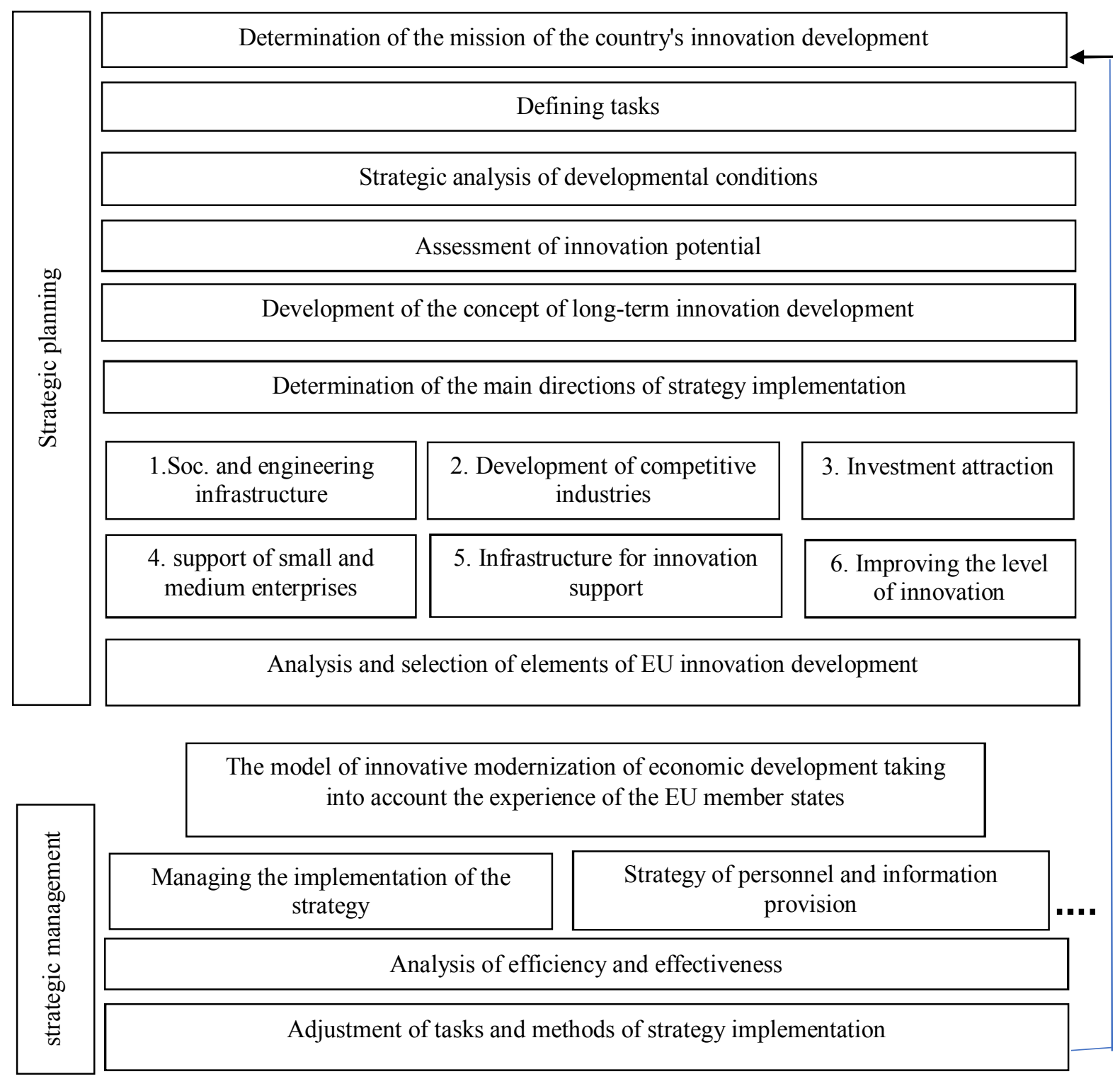

Fig. 3 Stages of modeling of innovation modernization of the Ukrainian economy. Source: developed by the authors.

The key to the development of the plan and projects is the model of innovative modernization of economic development, considering the experience of the EU member states as a form of private-public partnership with the use of science-intensive technologies (on technological platforms), which is presented in fig. 4. The presented model provides for the possibility of adjusting the targets of innovative modernization of the Ukrainian economy considering the tasks of the formation of applied scientific and industrial relations of all subjects of innovation activity, to some extent responsible for the implementation of priority programs of scientific and technical development.
It should be noted that in order to implement the innovation modernization of the Ukrainian economy, it is necessary to improve the quality of the work of national financial institutions and ensure the effectiveness of the targeted redistribution of cash capital through the development of new financial mechanisms, which in this context represent a set of methods, forms of financing and tools that regulate and ensure a stable innovative development of the Ukrainian economy. So, first of all, the tools of indirect support for innovation development, namely, the tax, price, depreciation and credit policies of the state should be used. 


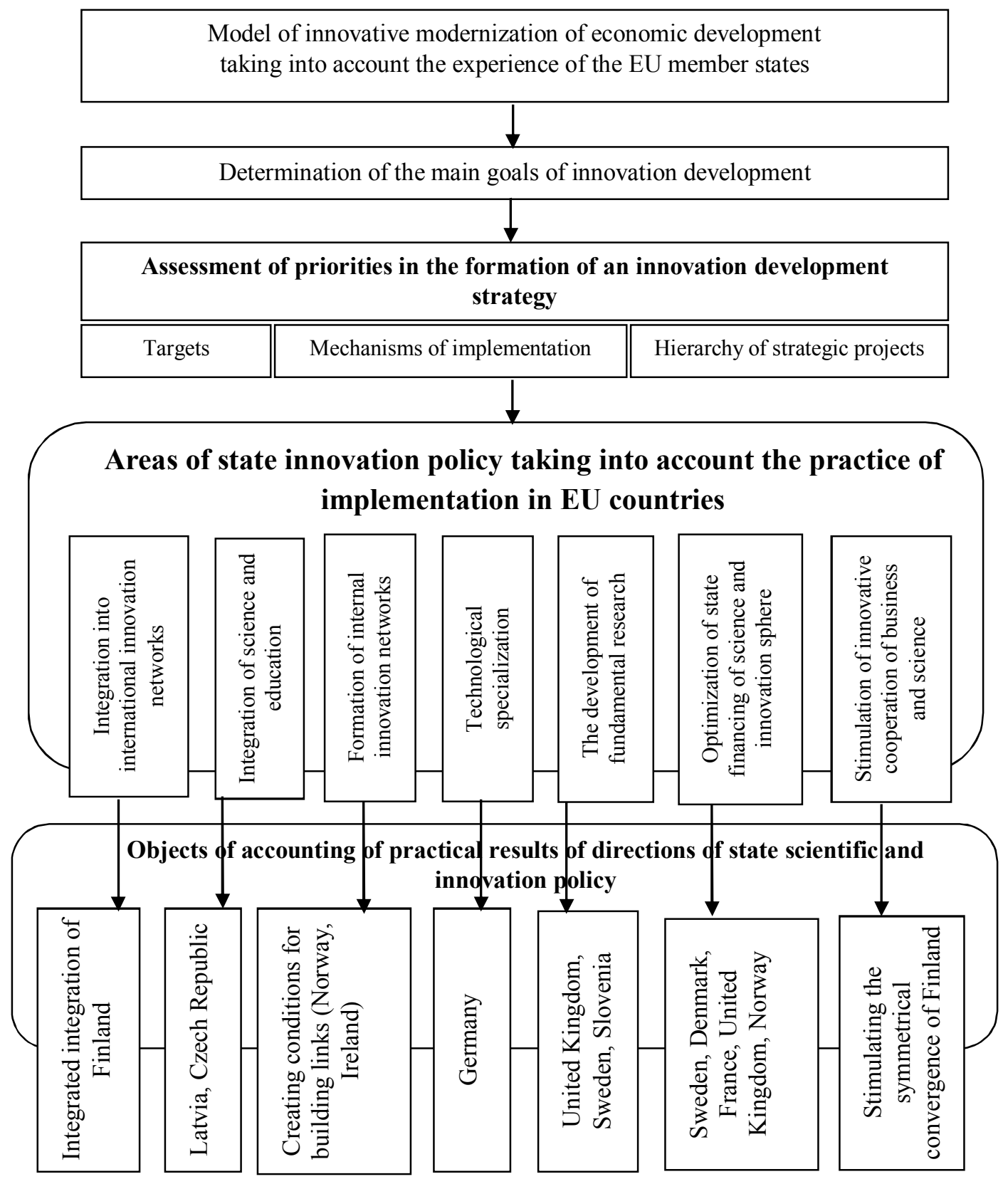

Standardization, planning, strategic setting of innovation development in accordance with existing conditions in the country

Fig. 4. Model of innovative modernization of economic development considering the experience of $\mathbf{E} \boldsymbol{U}$ member states

Source: developed by the authors.

The most popular mechanism for stimulating innovation development in European practice is tax support. Tax privileges have certain advantages over direct government funding, including government procurement and grant support. They are more in line with the principles of market regulation, reducing the marginal costs of private sector companies associated with research and development, and at the same time, leaving the right to choose the direction of search firms themselves.
At the same time, as a rule, it is assumed that tax privileges lead to an increase in private investment in the SRW, which in turn contributes to the increase of innovation activity and the rates of economic growth. At the same time, they can induce indirect effects, such as increased wages of scientists, the creation of new innovative enterprises, the increase of the economic potential of less developed regions, which create a more favorable tax climate, etc. 
For these reasons, they are becoming widespread in many countries. According to the OECD, tax incentives for businesses operate in 26 out of 34 participating countries. They are widely used outside the OECD, in particular in BRICS and Singapore. In countries where such privileges are not yet available in relatively comparable amounts with other countries (eg Germany, Finland, Switzerland), debates are underway on the possibility of introducing additional duties in the future [18]. The tax incentive schemes existing in different countries differ markedly in terms of the scale of benefits, the forms of their provision, the goals and the entities that are their recipients. Similarly, countries use different tax incentive schemes, either tied to either the absolute volume of business investment in $R \& D$, or the growth of such investments in comparison with some baseline.
Recipients of benefits can be firms that conduct fundamental research, cooperate with universities and state research centers, implement energy-saving technologies, and master alternative energy sources. Special tax privileges are addressed to small and mediumsized businesses first created by firms (startups), companies that receive income from the sale of their intangible assets (intellectual property). Various current instruments of tax incentives for $R \& D$ in different countries are summarized by OECD experts in the table 1 [18]. Analyzing the above information, it should be noted that there is a difference in the ratio of the instruments under consideration: among the leaders in terms of tax privileges granted by France, Ireland, Portugal, Denmark, Hungary. At the same time, countries such as Germany, the Czech Republic, and Sweden prefer direct methods of state support.

Table 1. Instruments of tax incentives R\&D

\begin{tabular}{|l|l|l|}
\hline $\begin{array}{l}\text { Features of the } \\
\text { construction of the } \\
\text { scheme of tax } \\
\text { incentives R\&D }\end{array}$ & Volume tax credit for R\&D & France, Norway \\
\cline { 2 - 3 } & $\begin{array}{l}\text { Hybrid schemes combining different } \\
\text { forms of credit }\end{array}$ & Spain, Portugal \\
\cline { 2 - 3 } & Tax deductions for R\&D & $\begin{array}{l}\text { Austria, Hungary, Czech Republic Great } \\
\text { Britain, Denmark, }\end{array}$ \\
\hline Reduction of tax payments for staff associated with the R\&D & Belgium, Hungary, Spain, Netherlands \\
\hline \multirow{3}{*}{$\begin{array}{l}\text { Special tax } \\
\text { incentives }\end{array}$} & $\begin{array}{l}\text { for small enterprises in the field of } \\
\text { research work }\end{array}$ & Australia, Great Britain, Hungary \\
\cline { 2 - 3 } & In the field of cooperation & Hungary, Italy, Norway \\
\cline { 2 - 3 } & For new recipients of tax privileges & France \\
\cline { 2 - 3 } & For new firms and startups & Netherlands, France \\
\hline $\begin{array}{l}\text { The existence of a maximum amount of tax privileges that the } \\
\text { recipient can count on }\end{array}$ & Austria, Italy, Netherlands \\
\hline \multicolumn{2}{|l|}{ Tax privileges on R\&D, tied to gross income } & Belgium, Spain, Netherlands \\
\hline Lack of tax incentives for R\&D & $\begin{array}{l}\text { Germany, Luxembourg, Finland, Sweden, } \\
\text { Estonia }\end{array}$ \\
\hline
\end{tabular}

Source: compiled by [18].

It is important to note that the process of stimulating innovation activity is carried out purposefully, as the state regularly reviews the list of privileges. It allows to influence not only the structure and number of scientific and innovative organizations, but also the industrial structure of innovation activity. Such a mechanism of stimulation is also effective from the point of view of the phase of development of technology or technology, as well as the stage at which stage (recession or recovery) is one or another branch.
In the case of the acute need to change the outdated technology or the withdrawal of the industry from a crisis state, the state may resort to significant benefits, which, at first glance, appear to be not quite economically justified. This is confirmed by the fact that in some countries the amount of benefits exceeds investment. For example, in Belgium - 110\%. And in some EU countries (for example, Italy, France), the taxable income excludes $100 \%$ of the costs associated with the implementation of innovations [19]. 
Consequently, the system of privileges supported by competition provides a sufficiently high demand for research and innovation. It should be noted that the new interesting phenomenon in the practice of tax incentives for innovation activity of a number of European countries has been the recent decline in corporate income tax rates as a result of the sale of patented products. This practice has already been introduced in various forms in 7 European countries. Although the rules for granting this privilege vary considerably from one country to another, in the special literature, their totality is united by the general term "patent box" ("patent box") [20].

Unlike most widespread R\&D privileges aimed at creating favorable conditions at the initial stages of the innovation process, reducing the cost of research and development, the "patent window" creates tax incentives for the successful commercialization of the results of innovation activities. As a rule, these incentives are expressed in the establishment of a lower rate of taxation of profits. It thus encourages successful innovation, which depends largely on economic growth, competitiveness and job creation.

The presented analysis of the experience of European countries indicates the diversity of forms and methods of tax incentives for innovation activity of enterprises. It should be noted that the measures taken are, as a rule, an integral part of the general system of measures of regulation of the economy. At the same time, such measures have a common goal of increasing competitiveness by increasing the scale of research and development in the commercial sector and accelerating the process of launching new promising results on the market.

In turn, the optimal balance between two methods of investments - self-financing and budget financing of innovation development in Ukraine should be achieved through the application of flexible tax policy, which should be carried out in different directions. First of all, through stimulating the implementation of innovations. Secondly, when it is applied more actively the production is being developed, while the fixed capital is based on the latest technological principles. Thirdly, it gives an opportunity to influence enterprises and commercial structures, including banking, in the direction of increasing the volume of investments directed at innovation activities.

Along with this, the important directions of indirect stimulation of innovation development can be attributed:

- support by local authorities of preferential tariffs for the payment of utilities for innovative investment objects;

- permission of local and regional authorities to use certain resources representing contributions to shareholders' societies specially created for any innovation projects;

- guarantee of investment investments, also considering partial guarantees that will allow not to remove responsibility from the main investors, not allowing lobbying by officials of concrete projects;

- stimulating project bank lending through tax regulations, preferential loans and the use of other instruments.

Conclusions. As a result of the study of practice of state support for innovation activities in Ukraine and abroad, we can conclude that an effective system of state support for innovation modernization of the Ukrainian economy has not yet been formed. Existing support is fragmentary. One of the reasons for this situation, given the significant differences in capital investment in the field of innovation from other spheres of the economy, is the lack of scientific development of the basis for the creation of a national innovation system. The following areas can be considered as the most urgent areas for solving this problem:

- fundamental development and theoretical substantiation of the types of publicprivate partnership. Non-state capital often circumvents the sector of innovation by the party. The region, the state take part in financing the riskiest stages of the most important projects within the framework of implementation of the strategy of innovation development. But the methods of investing state funds in venture funds have not yet been developed, and without it it is useless to rely on their appearance in the foreseeable future.

- ensuring transparency of the system of stimulation of domestic innovation projects. Such a system should be reasonable and understandable to any investor who rely on any kind of financial support that exists in the state. 
These are preferential terms for tax credits, compensation for refinancing rates for bank loans, credit guarantees;

- formation of a stable information field, which includes a set of data on a number of issues arising (between private, state and mixed structures) that arise in the process of generating and using financial resources for the purpose of innovative development of the economy.

- Innovative development of Ukraine should be considered not only from the point of view of the interests of accelerating economic growth in the country, but also in terms of opportunities for international cooperation in research and development, which is expanding under the influence of transformational changes in the world economy, including the development of communications and internationalization science One of the manifestations of such cooperatives may be the development of innovative local and regional networks, the driving force of which is the interests of neighboring countries. This is particularly strikingly illustrated by the example of the EU, where there is a multi-level cooperation in the field of research and development. In order to increase the competitiveness of the innovative sphere of the Ukrainian economy, this plays a fundamental role, because on this basis, the new quality of the development of science in the European community was conditioned, when due to the cross-border movement of innovations and scientific staff opportunities for the expansion of scientific and technical cooperation at the level of corporations are provided, which significantly influences on the growth of the competitiveness of the economies of the EU member states.

\section{REFERENCE}

1. European Commission (2014). Communication from the Commission to the European Parliament, the Council, the European Economic and Social Committee and the Committee of the Regions for a European Industrial Renaissance. Com (2014) 14 Final. Brussels.

2. Lutskiv, O. (2015) Areas of interaction between Ukraine and the EU in the innovation sphere: expert commentary. State Enterprise Institute of Regional Studies M.I. Dolishni NAS of Ukraine. Lviv.[in Ukraine]

3. Mazaraki, A. (ed.). (2018). Ukrainian economy growth imperatives. Prague: Coretex CZ SE.

4. Atkinson, R. D. (2013). Competitiveness, Innovation and Productivity: Clearing up the Confusion. Washington, DC: The Information Technology \& Innovation Foundation.

5. Nelson, R. (2000). National innovation systems. In: Z. Acs (Ed.), Regional Innovation, Knowledge and Global Change (pp. 11-26). London: Pinter.

6. Kaiser, R., \& Prange, H. (2004). The reconfiguration of national innovation systems -the example of German biotechnology. Research Policy, 33(3), 395-408.

7. Dosi, G., Pavitt, K., \& Soete, L. (1990). The economics of technical change and international trade. LEM Book Series.

8. Nadiri M. (1993). Innovations and Technological Spillovers. NBER Workin Paper. No 4423. 27-33. DOI: $10.3386 /$ w4423

9. Godin, B. (2006). The linear model of innovation: The historical construction of an analytical framework. Science, Technology, \& Human Values, 31(6), 639-667.

10. Heyets, V. (2017) Why is it time to start from the beginning? Ukraine economy, 5-6, 3138 [in Ukraine].

11. Duginets, G. (2018). Global Value Chains. KYIV: KNUTE [in Ukraine].

12. Kvasha, O. (2016). Innovative development of economy of Ukraine: world experience and recommendations is for Ukraine. Scientific herald of Uzhgorod National University. Series: International Economic Relations and World Economy, 6 (1), 150-154 [in Ukraine].

13. Marchuk, L. (2011). Foreign models of innovative economic development: choice for imitation. Economy and region, 2 (29), 200-204 [in Ukraine]. 
14. Koval, V. (2019). Institutional determinants of state policy to regulate services markets. Social and legal aspects of the development of civil society institutions (pp.109-125). Part II.BMT Erida Sp. z o.o., Poland.

15. Koval, V., \& Weis, L. (2019). State regulation and investment management in the development of circular economy. Sustainable development under the conditions of European integration (pp. 296-309). Part I. Ljubljana: VŠPV, Ljubljana School of Business.

16. Dyer, A. R. (2016). Madness as Metaphor: Therapeutic Implications of Post-Critical Thought. Tradition and Discovery: The Polanyi Society Periodical,42(4), 23-33. DOI: 10.5840/traddisc201642430.

17. Malmberg, A., \& Maskell, P. (2018). Localised capabilities and industrial competitiveness. In Voices from the North (pp. 11-28). Routledge.

18. OECD (2011). The International Experience with R\&D Tax Incentives. Tax Reform Options: Incentives for Innovation. Testimony by the Organization for Economic Cooperation and Development. United States Senate Committee on Finance.

19. European Commission (2018). Innovation Statistic. Eurostat Yearbook online. Retrieved from http://epp.eurostat.ec.europa.eu/statistics_explained/index.php/Innovation_statistics.

20. Atkinson, R. D. (2015). An Easy Checkoff for Global Competitiveness: The Case for a US Innovation Box. Information Technology and Innovation Foundation. 